\title{
Self Service Technology and Customer Satisfaction in the Nigerian Online Sport Betting Industry
}

\author{
Ebuka Christian Ezenwafor ${ }^{1} \quad$ Adeola A. Ayodele ${ }^{1} \quad$ Panama, Amos Ejiroghene ${ }^{2}$ \\ 1.Department of Marketing, Nnamdi Azikiwe University, Awka, Nigeria \\ 2.Department of Petroleum Marketing and Business Studies, Petroleum Training Institute, Effurun Nigeria
}

\begin{abstract}
The eruption in technological innovation is felt in every industry of which the service industry is not exempted. This study examines the effect of SST on customer satisfaction among customers of the sport betting industry in a typical growing economy. Although extant literatures are replete with the effect of SST on customer satisfaction, empirical investigation on the nexus between e-service quality andcustomer satisfactions in the fast-growing sport betting sector is inchoate hence, earns the need for the research. The main objective is to empirically investigate on the nexus between SST and customer satisfaction. To achieve this objective, a survey research was adopted, and unit of analysis represented online bettors in Anambra state. Quota sampling andquestionnaire was the sampling technique and research instrument respectively. A sample size of was drawn using cochran's formula for unknown population. The internal consistency of the instrument was tested using Cronbach alpha coefficient test, with the entire variable above 0.70. The data was processed using SPSS version 23 and hypothesized nexus between SST and customer satisfaction analysed using multiple regression analysis. The finding revealed that accessibility, security and website design have a positive and significant effect on customer satisfaction while reliability showed a positive but non-significant relationship amongst online bettors in Anambra state. It was recommended that sport betting industry should ensure that their website layout is easily navigated and understood; that they should draw knowledge from banks and bear the data cost bettors incur in the process of betting. Finally, they should ensure a quick and prompt pay-out facility.
\end{abstract}

Keywords: Self Service Technology, Customer Satisfaction, Online Sport Betting, Nigeria

DOI: $10.7176 / \mathrm{EJBM} / 12-8-01$

Publication date:March $31^{\text {st }} 2020$

\section{Introduction}

The eruption in technology has created a quantum leap in competition and customers' sophistication which has evidently altered a lot of business operation, the alteration is greatly felt in the service industry which sport betting sector is a significant part of. Nigeria, a country with over 180 million persons and the largest/developing country in sub-Sahara Africa has witnessed an astronomical expansion and growth in the sport betting industry. Price water house coopers (2019) confirmed that the industry has been expanding drastically at a rate of $16 \%$ per annum from 2016 to the present date, hence It worth's above \$147 million in the year 2019 with a lot of prospect for further growth. This industry has contributed immensely to the economic development of the country and provided seemingly 40,000 jobs directly or indirectly (Akingbolu , 2019). This drastic growth and development in the betting industry is seemingly as a result of technological advancement. This technological advancement is visible in form of self service technology which allows customer perform their services themselves. Self service technology is technology interface that allows the customers to perform their services without the assistant of service employee (Meuter, Ostrom, Roundtree, \&Bitner, 2001).

Prior before now, betting industry was orthodox, Bettors have to walk humongous distance, stand in a queue and spend hours just to place a bet. More so, the societal value attached to bettors is appalling. Sequel to such belief, some of the customers of betting centres are not happy with the societal value attached to betting hence leading to psychological dissatisfaction. Admittedly, the innovation in technology, proliferation and acceptance of SST in betting industry seems to be as a result of some propelling factors. Firstly, societal perception of betting; before now, the society has been repulsive to betting and bettors because of its anticipated effect which could be on individual health, the family and social order (Dowling, Jackson, Swomi, Lavis \& Thomas, 2014; Thomas \& Thomas2015). The industry is attacked by cross section of Nigerians, who either criticise it based on religious conviction or ignorance of the operation (Akingbolu, 2019). Secondly, the level of competition in the betting industry has multiplied exponentially because of the envisioned opportunities in the industry (Liam, 2015 \& Digitalprime, 2018). Thirdly, the astronomical rate of mobile internet penetration. The increasing access to internet enabled device which Nigerian Communication Commission asserted has leaped from $36 \%$ to $50 \%$ in the last three years (Pwc, 2017). Finally, the level of dissatisfaction and inaccessibility of the orthodox betting platform by the bettors. Furthermore, the quantum advancement in technological innovation (digitalized form of betting) which plays out in betting industry has somewhat attended to some of the afore-mentioned factors.

Expectedly, extant literatures are gorged with established relationship between SST and customers satisfaction in various sectors (Mathew et al.,2000; Waleed et al., 2017; Christie \& Ira2015; Ludfi et al., 2014; 
Masabo, 2013 \&Owusu, \&Dwomoh, 2017). Oddly, there is a shortfall of such literature in betting industry in Nigeria and sub-Saharan region at large. Empirically, there is a need to investigate the effect of self service technology on customer satisfaction with emphasis in betting industry. Accordingly, this study aims to fill the gap by investigating SST and customer satisfaction in betting industry which has over the years witnessed tremendous change as a result technological innovation.

\section{Review of Related Literature}

\subsection{Self Service Technology}

The tremendous competition in global village and business environment at large, has lead to unending strive in businesses to keep up and fight back competitors. This has lead to astronomical leap in technology, and highly proliferated in self service technology self. It provides an interactive platform for the customer and organisational representative (technological interface). Technology at this length, has assumed duties of most functions accredited to employees of organisation which betting industry is not exempted. According to Mathew, et al (2001) self service technology are technological interface that allows the customer to perform its needed services without the assistant of organisation employee. Similarly, customer interacts with technological interface to deliver services in cyberspace where no interpersonal relationship is established. More so, Christie et al (2015) asserts that self service technology is operational situation where customers deliver services themselves using any form of technological interface. Meuter et al (2000) postulate that SST are technological interface that aids customers receive service without the direct involvement of employee. Extant literatures (Meuteret al 2000; Muhammad,et al 2018 \&Sia, 2013) postulate that technology has a way of improving service quality hence, beneficial to both the customer and the firm Admittedly, self service technology in betting industry could be in the form of online betting, app betting and orthodox shop self booking etc. interestingly, the advancement in betting industry is aim at promoting efficiency and better service quality which transcends to customer satisfaction.

\subsection{Customer Satisfaction}

In the ever-competing business environment, organisations have germane objective of satisfying the customer since it is pivotal in achieving the organisation overall goal. Satisfaction can be a feeling of fulfilment over a received service. According to Anderson (1994) customer satisfaction is defined as over all organisation performance in the perspective of a customer. Ranaweera \& Prabhu (2003) assert that if customers are satisfied with goods and services received, they would be motivated to be loyal to that brand. According to Kotler \& Susnto (2000), customer satisfaction is defined as how the customer feels about a product after comparing the performance of a product with what they expected of the product/services. If the performance exceeds expectation, the customer is satisfied. Contrary to that, if the performance falls below expectation the customer is dissatisfied.

\section{Hypotheses Development}

3.1 Relationship Between Ease of Use and Customer Satisfaction.

According to Santos (2003) ease of use is the ability of the customer to perform transactions effortlessly on the cyberspace, internal navigation and search within the website. The effortlessness can be observed in how well organized, structured and easy to surf the site etc. Mathew, et al (2000) in their study asserts there is a significant relationship between ease of use and customer satisfaction in banking industry Usa. Furthermore, Waleed, et al (2017) posits that all the studied elements of which ease of use is not exempted have a positive significant relationship with customer satisfaction. The aforementioned study was carried out in turkey and in banking sector. Additionally, Christie, et al(2015) studied the effect of self service technology towards customer satisfaction. Eservice quality was measured holistically without examining the effect of individual variable on customer satisfaction. In the same light, it found that SST has a significant effect, on customer satisfaction in Indonesia with emphasis on G.S restaurant. As asserted by Masabo, (2013) most of the respondent agreed that ease of use of service through e-service channels have a significant effect on satisfaction in Kenyan banking industry. However, amongst these literary establishments, oddly, none of these have divulged the relationship between ease of use and customer satisfaction in betting industry. Therefore, we hypothesized as follows:

$\mathbf{H}_{1}$ : There is a significant relationship between ease of use and customer satisfaction.

3.2 Relationship Between Reliability and Customer Satisfaction.

According to Santos (2003) reliability is the ability to perform the promised service accurately and consistently. It is most germane determinant in the active dimension of E-service quality. It can be said to be the customer's trust that the channel will deliver the promised services (Merilee \& Louis 2003). More so, Ojasalo (2010) proposed that reliability involves consistency of performance and reliability that is performing promised services right the first time and always. Furthermore, according to Masabo (2013) there is a significant relationship between reliability and customer satisfaction. More so, umpteen conceptual literatures (Raman, S.A et al 2008; Lee \& Lin 2005; Wolfinbarge \& gilly 2003; Santos, 2003) have found a great importance of reliability as one dimension of self 
service technology. However, there is a slender of extant literatures in effect of reliability on customer satisfaction in betting industry. From the foregoing, we hypothesize

$\mathbf{H}_{2}$ : There is a positive significant relationship between reliability and customer satisfaction.

3.3 Nexus Between Security and Customer Satisfaction.

According to (Ojasato 2010; Santos J. 2003), security is defined as freedom from risk, damage or doubt. Admittedly, most of the internet transactions are susceptible to risk. But the question is what customers feel when transacting with a particular service provider. What antecedent are customers looking for before transacting with a provider? Similarly, Waleed et al.(2017) postulatesthat security is somewhat related to how secured the customers feel when using the SST channels and how well their privacy is protected. More so, extant literatures (Santos, 2003; Waleed et al., 2017; Ojasato, 2010; Masabo, 2013; Muhammad et al., 2018) are gorged with the relationship between security as one of the dimensions of e-service quality and customer satisfaction in various industries and countries which showed a significant relationship between security and customer satisfaction. Oddly, no study has focused on the effect of security consciousness on customer satisfaction in betting industry. Therefore, we hypothesized as follows:

H3: There is a significant relationship between security and customer satisfaction.

3.4 Relationship Between Website Design/ Appearance and Customer Satisfaction.

According to Muhammad, S.I. et al (2018), website design is the overall layout of the system. Lee \& Lin (2005) defined website design as the appeal that the user interface presents to the customer. As asserted by Ojasato (2010), website design is defined as the degree of friendliness, graphics, colour, image and easy navigation in using the site and its compatibility in various devices. Website appearance is the first thing a customer observes when he visits a webpage.

More so, Matthew et al. (2000) posit that webpage design has a significant relationship with webpage visit but cannot predict if that influences customer satisfaction. Waleed et al. (2017) studied website design as part of its service quality. This study found out that XTM service quality has a significant effect on customer satisfaction. Furthermore, Cho \& Park (2001) in their study, development of electronic commerce user consumer satisfaction index (ECUSI) for internet shopping found a significant relationship between website design and customer satisfaction in an online shopping industry. As postulated by Wolfinbarger et al. (2003), website design is a strong predictor of customer quality, judgment, satisfaction and loyalty for internet retailers. Muhammad et al. (2017) found a significant relationship between website design and customer satisfaction in Pakistan's banking industry. However, extant literatures are subsumed with relationship between website design and customer satisfaction. Oddly, there is an existing gap in betting industry which prompted to hypothesize as follows:

$\mathbf{H}_{4}$ : There is a significant relationship between website design and customer satisfaction in betting industry.

\section{Materials and Methods}

Data was collected through the administration of structured questionnaire to 236 respondents who are online bettors and have betted for more than 3 months. The inclusion of betting duration is to ensure the respondent have the required degree of exposed and must have used more than one betting platform over this time.

The questionnaire was designed to measure e-service quality and customer loyalty. E-service quality scale was adopted from Ojasato (2010) which has 8 construct of which four (4) was selected because of its appropriateness in the context under study. The items include; ease of use, reliability, website design and appearance, and security. Similarly, the question scale of customer satisfaction was adapted from djajanto, nimran, kumadji \& kertahadi (2014). Kaiser-Meyer-Oklin (KMO) measures sampling adequacy with value of .949 which is far above the 0.5 threshold. The Bartlett's test of sphericity has approximate chi-square value of 9826.1 which was significant at .000 well below the .05 margin of error.

\section{Testing of Hypotheses}

The formulated hypotheses were tested using multiple regression analysis with the aid spss version 22 . The $\mathrm{R}$ value of .991 shows a strong, positive and significant relationship exists between the dimensions of SST and customer satisfaction. R-square value of .982 shows that variation in customer satisfaction is predicted by the four (4) independent variables. The ANOVA results shows a statistical significant relationship SST and customer satisfaction $F(4,231)=3093.03, p<0.00$. This means that the variable is a good fit and can be used to explain variation in the dependent variable. For the regression coefficient, security, accessibility and website design was found to be statistical significant at $(\beta=0.52, \mathrm{p}<0.05),(\beta=0.11, \mathrm{p}<0.05)$ and $(\beta=0.29, \mathrm{p}<0.05)$ respectively thus, hypothesis 1,2 and 4 was accepted. Reliability was found to be statistically not significant $(\beta=0.08, p>0.05)$ thus, hypothesis 3 was rejected. Security has the most effect on customer satisfaction with and significant at $(\beta=0.52$, $\mathrm{T}=10.49, \mathrm{p}<0.05)$. 


\begin{tabular}{|c|c|c|c|c|}
\hline \multicolumn{5}{|c|}{ Table 1: Model Summary } \\
\hline $\begin{array}{l}\text { Mod } \\
\text { el }\end{array}$ & $\mathrm{R}$ & R Square & $\begin{array}{l}\text { Adjusted R } \\
\text { Square }\end{array}$ & Std. Error of the Estimate \\
\hline 1 & $.991^{\mathrm{a}}$ & .982 & .981 & .141 \\
\hline
\end{tabular}

a. Predictors: (Constant), accessibility, website, Reliability, SECURITY

Table 2: ANOVA ${ }^{\mathrm{a}}$

\begin{tabular}{ll|r|r|r|r|r} 
Model & & Sum of Squares & Df & Mean Square & F & Sig. \\
\hline \multirow{2}{*}{1} & Regression & 247.371 & 4 & 61.843 & 3093.036 & $.000^{\mathrm{b}}$ \\
\cline { 2 - 7 } & Residual & 4.619 & 231 & .020 & & \\
\cline { 2 - 7 } & Total & 251.990 & 235 & & & \\
\hline
\end{tabular}

a. Dependent Variable: customer satisfaction

b. Predictors: (Constant), accessibility, website, Reliability, SECURITY

\begin{tabular}{|c|c|c|c|c|c|c|}
\hline \multicolumn{7}{|c|}{ Table 3: Coefficients ${ }^{a}$} \\
\hline \multirow[b]{2}{*}{ Model } & & \multicolumn{2}{|c|}{$\begin{array}{l}\text { Unstandardized } \\
\text { Coefficients }\end{array}$} & \multirow{2}{*}{$\begin{array}{c}\text { Standardized } \\
\text { Coefficients } \\
\text { Beta }\end{array}$} & \multirow[b]{2}{*}{$\mathrm{T}$} & \multirow[b]{2}{*}{ Sig. } \\
\hline & & $\mathrm{B}$ & Std. Error & & & \\
\hline \multirow[t]{5}{*}{1} & (Constant) & -.035 & .029 & & -1.193 & .234 \\
\hline & SECURITY & .528 & .050 & .516 & 10.489 & .000 \\
\hline & Website & .116 & .044 & .111 & 2.630 & .009 \\
\hline & Reliability & .095 & .047 & .083 & 2.026 & .044 \\
\hline & Accessibility & .263 & .033 & .292 & 7.966 & .000 \\
\hline
\end{tabular}

a. Dependent Variable: customer satisfaction

\section{Discussion of Findings}

This study was triggered by the desire to assess the nexus between self-service technology and customer satisfaction in the sport betting industry. It was based on sample 246 retail bank customers in selected State of which 236 responded. The study was based on four independent variables: security, reliability, ease of use and website design / appearance while customer satisfaction was the dependent variable. The descriptive analysis of the data shows that young and middle age customers are more inclined to explore innovations like the SST channels: online betting, mobile sport betting than the older counterpart. The study also shows that online betting is the most preferred channel among all the SST channels. This finding is in line with the assertion of Owuor (2018). The study found out that there is a significant relationship between SST security and customer satisfaction with betting firms. This finding concurs with view point of (Masabo, 2013; Muhammad et al., 2018). It is also in line with Liao and Cheung (2003) that security of operations is important to customers when considering SST channels. It was also found out that reliability is not significant with SST channels. This opposes the finding of (Lee et al., 2005; Wolfinbarge et al., 2009; Santos, 2003)earlier cited in the literature. The study also found out that ease of use and website design and appearance have significant relationship with SST channels.

\section{Conclusion}

This work concerns self-service technology and customer satisfaction in the Sport betting industry: a study of sport betting bettors in Anambra State. The study is anchored on E-service quality model from which we extracted four independent variables: security, ease of use, website design/appearance and reliability while the dependent variable is customer satisfaction. The data collected was analysed using both descriptive and inferential statistics. Based on the analysis the following conclusions are made. Online betting is the most preferred channel for performing betting services through the SST. That is to say that online betting is the most patronized SST channel. Security of SST channel has a significant and positive effect on customer satisfaction with betting industry. Reliability of SST channel was not related to customer satisfaction with betting firms. Also website design/appearance and accessibility have significant and positive relationship with satisfaction with betting industry.

\section{Recommendations}

There is need in proper follow up of technological advancement to ensure bettors get best of value for money. Secondly, sport betting company can provide an easily accessible interface that will be easily navigated among the bettors because a reasonable percentage of their customers are uneducated. Sport betting industry can draw strategy from banking industry and provide uninterrupted internet facilities for their customer, betting firms will bear the cost of data consumed by their customer in the process of betting. The industry should work on their pay-out time to enable bettors have their returns at the most needed time. 


\section{References}

Akingbolu, H. (2019). Examining growing culture of sports betting. https://www.pressreader.com/Nigeria/thisday/20190606/281904479673753

Anderson, E.W., Fomel, C \& Lehmann, D.R(1994). Customer satisfaction, Market Share and Profitability. Journal of marketing, 58, 53-66.

Christie, C.S \& Ira, F (2015). The influence of self service technology (SST) towards customer satisfaction. Journal of business and management, 4, 6728-742.

Dowling, N., Jackson, A., Swomi, A., Lavis, T \& Thomas, S. (2014). Problem gambling and family violence: prevalence and pattern in treatment seekers and addictive behaviour. 39(12)

Gerda, R., Fiona, D. \& Jane, k. (2011). Understanding Gambling: Impacts and Social Network across the Life course.

Isaiah, M. (2019). Advantages of online betting. Retreived from www.betshop.com/betting-guides/advantages of-online-betting/.

Liao, Z. \& Cheung, M.T. (2003). Challenges to Internet E-Banking. Communications of the ACM, 46(12), 248250.

Lee, G. \& Lin, H. (2005). Consumer perception of e-service quality in online shopping. International journal of retail \& distribution management 33(2); 161-176.

Liam, C. (2015). I gaming and business: product innovation in sporting betting. https://igamingbusiness.com/product-innovation-sports-betting-whats-next.

Djajanto, L., Nimran, U., Kumadji, S \& Kertahadi (2014). Effect of self service technology, service quality and relationship marketing on customer satisfaction and loyalty. Journal of business management, 16, 31-50.

Masabo, H.O. (2013). Self service technology and customer satisfaction in commercial bank in Kenya.

Mathew, L.M., Amy, L.O., Robert, I.R \& Mary, J.B. (2000). Self service technology: understanding customer satisfaction with technology- based service encounter. Journal of Marketing, 64, 50-64.

Meuter, M.L., Ostrom, A.L., Roundtree, R.I \&Bitner, M.I(2000). Self service technologies: Understanding consumer satisfaction with technology- based services service encounter. Journal of Marketing, 64, 50-64.

Muhammad, S.I., Masood, U.H. \& Ume, H. (2018). The impact of sst service quality on customer loyalty and behavioural intention: the mediating role of customer satisfaction. Cogent business and management, 1-23.

Namjae, C. \& Sanghyuk, P. (2001). Development of electronic commerce user-consumer satisfaction index (ECUSI) for internet shopping. Industrial management and data system. 400-405.

Ojasalo, J. (2010). E- Service quality: A Conceptual Model. International Journal of Arts and Science, 3(7), 127143.

Owusu, A. \& Dwomoh, H.A. (2017). Investigating customer satisfaction level with self service technology within banking sector. America journal of operations management and information system, 2, 97-104.

Parasuraman, A. \& Grewal, D. (2000). The impact of technology on the quality-value-loyalty chain: a research agenda. Journal of the academy of marketing science, 28(1), 168-174.

Parasuraman, A., Zeithaml, V.A \& Berry, L.L. (1985). A conceptual model of service quality and its implication for future research. Journal of Marketing, 49, 41-50.

Price Water Cooper (2017). The Nigeria Gaming Industry. Price water house coopers limited.

Ranaweera, C. \& Prabhu, J. (2003). The influence of satisfaction, trust and switching barriers on customer intention in a continuous purchase setting. International journal of service industry management, 14(4).

Ray G., Thomas, J.Z. \& Marick, F.M. (2009). Encyclopaedia of human resource information system: Challenges in e-HRM. IGI Global.

Ryan, B., Dennis, C.J. \& Frances, F. (2009). Are self service customers satisfied or stuck? POMS 20th annual conference.

Thomas, S.L., Thomas, S.M.D. (2015). The big gamble: the need for a comprehensive research approach to understanding the cause and consequence of sampling harm in austrialia. Australas Epidenial, 22(1),39- 42.

Waleed, M., Busra, M. \&Oya, E. (2017). An investigation of self service technology participation banking in turkey. Journal of economics, finance and accounting. 145-153.

Wolfinbarger, M and Gilly, M.G. (2003). Etailing: dimensionalising, measuring and predicting etail quality”, journal of retailing, 79 (3), 183-198. 